\title{
CORRELATION BETWEEN ALBUMIN CREATININE RATIO WITH THE LEFT VENTRICULAR HYPERTROPHY IN MALE CENTRALLY OBESE
}

\author{
Frans E. Wantania \\ Department of Cardiology and Vascular Medicine, \\ Faculty of Medicine, Sam Ratulangi University, Prof RD Kandou Hospital, Manado \\ Email: Akuaku_ukauka@ymail.com
}

\begin{abstract}
Abstrak: Hipertrofi ventrikel kiri (LVH) merupakan faktor risiko independen untuk kejadian kardiovaskular. Penelitian akhir-akhir ini memperlihatkan korelasi antara rasio albumin kreatinin (ACR) dan massa ventrikel kiri (LVM) pada pasien hipertensi, namun penelitian sebelumnya memperlihatkan LVH sering ditemukan pada laki-laki dengan obesitas sentral tanpa disertai hipertensi. Tujuan penelitian ini untuk menentukan korelasi antara ACR dan LVH pada laki-laki dengan obesitas sentral. Penelitian ini menggunakan desain potong lintang dan dilakukan di Bagian Jantung dan Pembuluh Darah RS Prof. Dr. R.D. Kandou Manado. Subyek penelitan berjumlah 33 orang laki-laki berusia 20-35 tahun dengan obesitas sentral, tanpa disertai diabetes melitus atau hipertensi. LVM ditentukan dengan menggunakan $M$ Mode dan 2D echocardiogram sedangkan ACR diukur dengan alat Vitros 950IRC. Hasil penelitian memperlihatkan bahwa pada sebagian besar subyek terdapat peningkatan LVM. Terdapat korelasi positif antara lingkar perut dan peningkatan LVM $(\mathrm{r}=0,801 ; P<0,001)$, serta antara lingkar perut dan ACR $(\mathrm{r}=0,691 ; P<0,001)$. Juga terdapat korelasi positif antara ACR dan LVM $(r=0,749 ; P<0,001)$. Simpulan: Terdapat korelasi positif antara rasio albumin kreatinin dan massa ventrikel kiri yang diukur dengan M-Mode dan 2D ekokardiogram pada laki-laki dengan obesitas sentral. Diharapkan rasio albumin kreatinin dapat dimanfaatkan untuk deteksi dini hipertrofi ventrikel kiri pada laki-laki obes.
\end{abstract}

Kata kunci: rasio albumin kretinin, massa ventrikel kiri, obesitas sentral.

\begin{abstract}
Left ventricular hypertrophy (LVH) is an independent risk factor for cardiovascular events. Recent study shows the correlation between the albumin creatinine ratio (ACR) and the left ventricle mass in hypertensive patients. However, our previous study showed that $\mathrm{LVH}$ was common in male central obesity without hypertension. The aim of this study was to determine the correlation between ACR and the LVH in male central obesity. This was a cross-sectional study conducted at the Department of Cardiology and Vascular Medicine of Prof Dr. R.D. Kandou Hospital Manado. The subjects were 33 males aged 20-35 years with central obesity, but without diabetes or hypertension. The left ventricular mass (LVM) was determined by using M-Mode and two-dimension echocardiogram. The albumin creatinine ratio was measured by using Vitros 950IRC instruments. The results showed that most of the subjects had an increase of left ventricular mass. There were positive correlations between waist circumference and the increase of $\operatorname{LVM}(\mathrm{r}=0.801 ; P<0.001)$ as well as between waist circumference and ACR $(\mathrm{r}=0.691 ; P<0.001)$. We found a positive correlation between ACR with the LVM in centrally obese males $(r=0.749 ; P<0.001)$. Conclusion: There was a positive correlation between the albumin creatinine ratio with the left ventricular mass using M-Mode and the 2D echocardiogram in centrally obese males. The albumin creatinine ratio may be helpful for the early detection of LVH in obese males.
\end{abstract}

Keywords: albumin creatinine ratio, left ventricular mass, central obesity. 
Obesity is steadily increasing world-wide including children and adolescents. The number of overweights has doubled in the last 2-3 decades and is a major concern of public health. ${ }^{1}$ This state is associated with significant cardiac abnormalities such as left ventricular hypertrophy $(\mathrm{LVH})$ and congestive heart failure. There are other numerous studies suggesting that obesity is a risk factor for $\mathrm{LVH}$ in any population, but the majority of these studies involving adult patients. $^{2}$

In obesity, adipose tissue releases proinflammatory cytokines such as TNFalpha that makes LDL be oxidized by ROS, with an acceleration of NO degradation resulting in endothelial dysfunction. ${ }^{3}$ Microalbuminuria is a marker of extensive endothelial dysfunction or generalized vasculopathy, which may lead to an increase of left ventricular mass (LVM) in hypertension. However, previous studies found non-diabetic and non-hypertensive obesity with an increase of LVM. ${ }^{4}$ This study aimed to determine the association of the albumin creatinine ratio (ACR) with the LVM in centrally obese males.

\section{METHODS}

This was a cross-sectional study conducted at the Department of Cardiology and Vascular Medicine at Prof dr. R.D. Kandou Hospital Manado. The subjects were 33 males aged 20-35 years with central obesity, but with no diabetes and no hypertension. Abdominal obesity is determined if wasit circumference (WC) $>90 \mathrm{~cm}^{5}$ Blood pressure was measured after at least 30 minutes of rest and average of 2 recordings were made. The LVM was determined by using the M-Mode and the two-dimension echocardiogram. The ACR was measured by using the Vitros 950IRC instruments and the Array 360 CE Protein Analyzer. Laboratory examinations were carried out at the Prodia Clinical Laboratory, Manado after the subjects signed an informed consent.

\section{RESULT}

In this cross-sectional study, most of the subjects had an increase of LVM. The average WC in central obesity was 108.9 $\mathrm{cm}$. The mean level of LVM was $271.8 \mathrm{~g}$. The average systolic blood pressure (SBP) was $127.7 \mathrm{~mm} \mathrm{Hg}$ while the average diastolic blood pressure (DBP) was 79.2 mm Hg. The mean level of ACR was 15.9 (Table 1).

Table 1. Characteristics of subjects

\begin{tabular}{lccc}
\hline \multicolumn{1}{c}{ Variables } & n & Min-Max & Mean (SD) \\
\hline Age (years) & 33 & $20-35$ & $28.8(8.2)$ \\
WC (cm) & 33 & $92-127$ & $102,2(9,6)$ \\
SBP (mmHg) & 33 & $110-135$ & $127.7(11.7)$ \\
DBP (mmHg) & 33 & $70-85$ & $79.2(7.2)$ \\
BW (kg) & 33 & $72-108$ & $88.9(8.1)$ \\
ACR & 33 & $5-45$ & $15.9(10,9)$ \\
LVM & 33 & $118-568$ & $268.8(95.9)$ \\
\hline
\end{tabular}

There was a positive correlation between WC and the increase of LVM ( $\mathrm{r}=$ 0.595; $P<0.001$; Figure 1 ), and a positive correlation between WC and the increase of ACR $(r=0.463 ; P<0.001$; Figure 2$)$

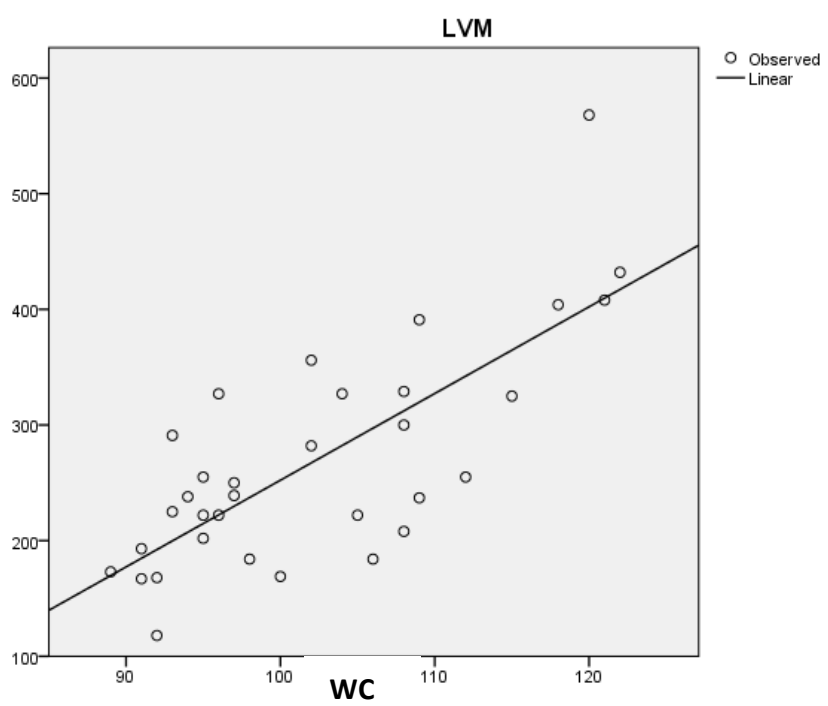

Figure 1. Correlation between LVM and WC. 


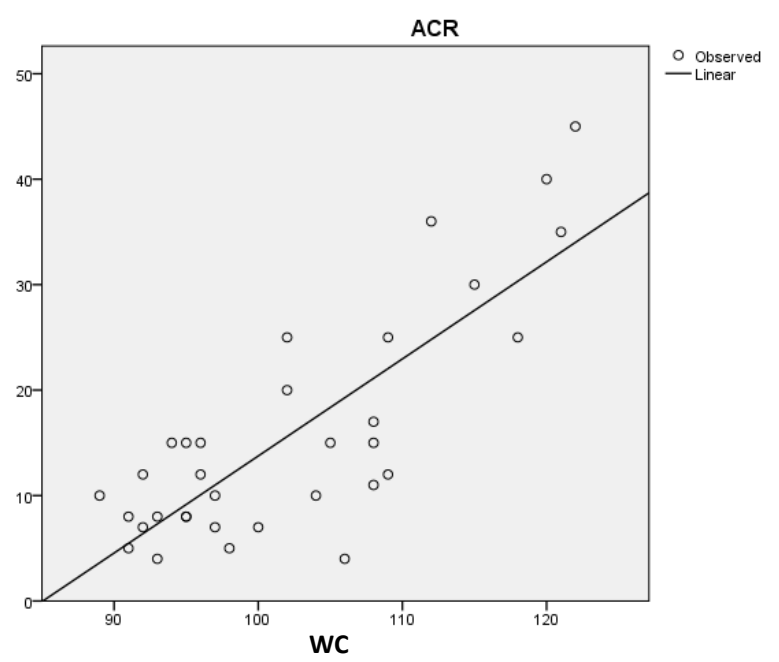

Figure 2. Correlation between WC and ACR.

We also found a positive correlation between ACR with the LVM in centrally obese males ( $r=0.722 ; P<0.001$; Figure 3 ).

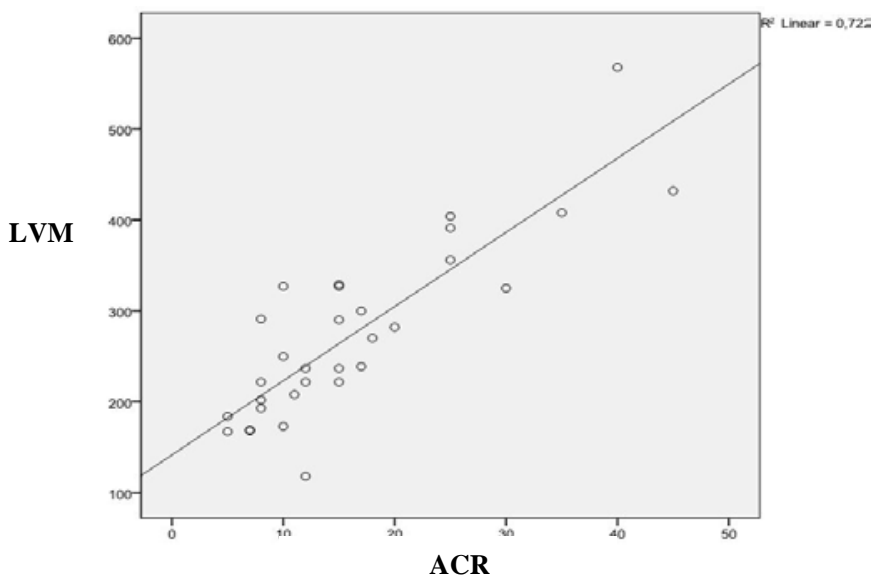

Figure 3. Correlation between LVM and ACR.

\section{DISCUSSION}

Our study is concordant with previous studies which found an increasing prevalence of LVH in asymptomatic obese adolescents. ${ }^{6}$ Increased cardiac workloads and visceral adipose tissue may contribute to the development of $\mathrm{LVH}$ in obese subjects. ${ }^{5}$ Previous studies have shown that IL-6 and TNF alpha were associated with progressive LV dysfunction, LV remodelling, myocyte hypertrophy, and myocyte apoptosis. Some mechanisms suggested for these include: immune activation, myocardial biosynthesis of inflammatory markers, underperfusion of systemic tissues, absorbtion of endotoxins from the edematous intestines, and neurohormonal activation. ${ }^{7}$

In fact, there is ample evidence that the accumulatian on of adipose tissue may determine cardiovascular alterations in several metabolic and neurohormonal pathways causing abnormalities in managing sodium, neuroendocrine activation, and the renin-angiotensin-aldosterone system, and increasing myocardial oxidative stress. Change in myocardial metabolism has been demonstrated in obese patients with a shift toward free fatty acid utilization and subsequent cardiac lipotoxicity, resulting in cardiomyocyte apoptosis and reduced cardiac efficiency. ${ }^{8}$

A previous study found microalbuminuria as a parameter of endothelial dysfunction in $5.72 \%$ of the samples and "high normal" ACR in 11.4\%..$^{9}$ This slightly elevated ACR $(15-30 \mu \mathrm{g} / \mathrm{ml})$ was associated with the increasing risk of cardiovascular events. The Copenhagen City Heart Study showed a 2.3 fold higher relative risk of cardiovascular events in their population with a "high normal" ACR over normal ACR $(<15 \mu \mathrm{g} / \mathrm{ml}) .{ }^{10}$ Picchi et al. ${ }^{11}$ found a decreased ability of endothelium vasodilatation in Zucker obese fatty (ZOF, a model of prediabetic metabolic syndrome) rats.

The mechanisms linking microalbuminuria and risks for cardiovascular disease are not fully understood, but in subjects at risk it may be related to increased transvascular leakiness of albumin in systemic as well as renal vessels. A recent concept is that microalbuminuria is a marker of extensive endothelial dysfunction or generalized vasculopathy, which may lead to heightened atherogenic states. One possible explanation is that endothelial dysfunction might promote increased penetration of atherogenic lipoprotein particles in the arterial wall. $^{4}$ 
This study found a positive correlation between LVH and ACR. It suggests that microalbuminuria can lead to an increase of LVM in obese adolescents. Progressive regional myocardial systolic or diastolic dysfunction is associated with renal dysfunction in a subset of Multi-Ethnic Study of Atherosclerosis (MESA) participants. Albuminuria is considered as a marker of microvascular and macrovascular diseases, and it has been associated with several cardiovascular risk factors and inflammatory markers. ${ }^{12}$

In 2003, Palmieri et al. ${ }^{13}$ investigated 1299 adults with type II diabetes in order to study microangiopathy and albuminuria as markers of endothelial dysfunction and its impact on the relation of $\mathrm{LVH}$ and inflammatory markers. They found a significant elevation of hsCRP, fibrinogen, and urinary albumin/creatinine among the persons with $\mathrm{LVH}$ compared to those without LVH (independent of plasma creatinine levels and cardiovascular risk factors). Fibrinogen and hsCRP levels were significantly higher in participants with LVH among those without pathological levels of urinary albumin indicating that the relation between the $\mathrm{LVH}$ and the inflammatory response may preceed a clinically relevant albuminuria. ${ }^{13}$

How CRP might drive LVH is not clear. It is possible that CRP could induce direct myocardial effects, as CRP can cause intimal hypertrophy both in vitro and in animal studies. ${ }^{14}$ Alternatively, such effects might be indirect as studies of transgenic mice have associated CRP with the development of hypertension and perivascular fibrosis. ${ }^{15}$ HsCRP itself decreases production of nitric oxide in endothelial cells and upregulates angiotensin type-I receptor expression. These known actions of hsCRP on angiotensin II receptors and in the production of nitric oxide can offer causative links between inflammation, the renin-angiotensin system, and $\mathrm{LVH}^{14}$ On the other hand, hsCRP is produced by the liver in response to a stimulation of IL-6, and is also produced by smooth cells and adipocytes. In several experimental studies,
IL-6-associated pathways played an important role in cardiomyocyte hypertrophy and cardiac fibroblast proliferation, and these effects were mediated by angiotensin II via the angiotensin type-I receptor as well as activated by glycoprotein 130-linked signaling pathways. ${ }^{16}$

Obesity related cardiac structural abnormalities appear to involve any age. Obese children $<16$ years old have been found to have significant LVH and abnormal diastolic parameters. Alterations in cardiac structure may be present even without any clinical signs of heart disease. It is apparent from this study that a variety of adaptations and alterations in cardiac structure occur as excessive adipose tissue accumulates even in the absence of systemic hypertension of underlying organic heart disease. ${ }^{17}$ Cardiovascular risk factors and cardiac structural changes associated with obesity are also major determinants of LV diastolic function. Left ventricular diastolic dysfunction is an asymptomatic condition that reflects an impairment of the filling properties of the left ventricle that has been demonstrated to be a predictor of future development of heart failure in obese populations. ${ }^{18,19} \mathrm{~A}$ recently published study suggests that obesity related cardiac abnormalities in adolescents are reversible after weight lost. Weight reduction regresses left ventricular hypertrophy and this occurs regardless of whether the subjects have normal or high blood pressure. $^{20}$

\section{CONCLUSION}

In this study, there was a positive correlation between waist circumference and the increase of left ventricular mass, and a positive correlation between waist circumference and the increase of ACR. We also found a positive correlation between ACR with the LVM in centrally obese males. The albumin creatinine ratio may be helpful for the early detection of left ventricular hypertrophy in obese male adolescents. 


\section{REFERENCES}

1. Sorof $\mathbf{J}$, Daniels S. Obesity hypertension in children: a problem of epidemic proportions. Hypertension. 2002;40:441-7.

2. Alpert MA. Obesity cardiomyopathy: pathophysiology and evolution of the clinical syndrome. Am J Med Sci. 2001;321:225-36.

3. Hajer GR, Haeften TW, Visseren FLJ. Adipose tissue dysfunction in obesity, diabetes, and vascular diseases. Eur Heart Journal. 2008;29:2959-71.

4. Naidoo DP. The link between microalbuminuria, endothelial dysfunction and cardiovascular disease in diabetes. Cardiovasc J S Afr. 2002;13(4):194-9.

5. Palmieri V, de Simone G, Arnett DK, Bella JN, Kitzman DW, Oberman A, et al. Relation of various degrees of body mass index in patients with systemic hypertension to the left ventricular mass, cardiac output, and peripheral resistance. Am J Cardiol. 2001;88:1163-8.

6. Freiberg P, Allansdotter-Johnsson A, Ambring, Ahl $\mathbf{R}$, Arheden $\mathbf{H}$. Increased left ventricular mass in obese adolescents. Eur Heart J. 2004;25:98792.

7. Kenchaiah S, Narula J, Vasan RS. Risk factors for heart failure. Med Clin North Am. 2004;88:1145-72.

8. Gorzelniak K, Engeli S, Janke J, Luft FC, Sharma AM. Hormonal regulation of the human adipose-tissue reninangiotensin system: relationship to obesity and hypertension. J Hypertens. 2002;20:965-73.

9. Wantania F, Lefrandt RL, Pandelaki K. Adiponectin and TNF alpha levels in male obese adolescents and its correlation with the endothelial dysfunction. Annual Scientific Meeting of Indonesian Heart Association, 2011.

10. Lumeng CN, Bocizin JL, Saltiel AR. Obesity induces a phenotypic switch in adipose tissue macrophage polarization. $\mathrm{J}$ Clin. Invest. 2007;117:175-84.

11. Picchi A, Gao X, Belmadani S, Potter BJ, Focardi M, Chilian WM, et al. Tumor necrosis factor-alpha induces endothelial dysfunction in the prediabetic metabolic syndrome. Circ Res. 2006;99:69-77.

12. Stehouwer CD, Nauta JJ, Zeldenrust GC, Hackeng WH, Donker AJ, de Ottolander GJ. Urinary albumin excretion, cardiovascular disease, and endothelial dysfunction in non-insulin dependent diabetes mellitus. Lancet. 1992;340(8815):319-23.

13. Palmieri V, Tracy RP, Roman MJ, Liu JE, Best LG, Bella JN, et al. Relation of left ventricular hypertrophy to inflammation and albuminuria in adults with type 2 diabetes: the strong heart study. Diabetes Care. 2003;26(10):2764-9.

14. Wang CH, Li SH, Weisel RD, Fedak PW, Dumont AS, Szmitko P, et al. Creactive protein upregulates angiotensin type 1 receptors in vascular smooth muscle. Circulation. 2003;107:1783-90.

15. Vongpatanasin W, Thomas GD, Schwartz R, Cassis LA, OsborneLawrence S, Hahner L, et al. Creactive protein causes downregulation of vascular angiotensin subtype 2 receptors and systolic hypertension in mice. Circulation. 2007;115:1020-8.

16. Sano M, Fukuda K, Kodama H, Pan J, Saito M, Matsuzaki J, Takahashi T, Makino S, Kato T, Ogawa S. Interleukin-6 family of cytokines mediate angiotensin II-induced cardiac hypertrophy in rodent cardiomayocytes. J Biol Chem. 2000;275:29717-23

17. Alpert MA, Lambert CR, Terry BE, Cohen MV, Mukerji V, Massey CV, et al. Influence of left ventricular mass on left ventricular diastolic filling in a normotensive morbid obesity. Am heart J. 1995;130:1068-73.

18. Russo C, Jin Z, Homma S, Rundek T, Elkind MSV, Sacco RL, et al. Effect of diabetes and hypertension on left ventricular diastolic function in a high risk population without evidence of heart disease. Eur J Heart Fail. 2010;12:454-61.

19. Schillachi G, Pasqualini M, Verdecchia P, Vaudo G, Marchesi S, Porcellati C, et al. Prognostic significance of left ventricular diastolic dysfunction in 
170 Jurnal Biomedik (JBM), Volume 5, Nomor 3, November 2013, hlm. 165-170

essential hypertension. J Am Coll Cardiol. 2002;39:2005-11.

20. Ippisch HM, Inge TH, Daniels SR, Wang

B, Khoury PR, Witt SA, et al.
Reversibility of cardiac abnormalities in morbidity obese adolescents. J Am Coll Cardiol. 2008;51:1342-8. 